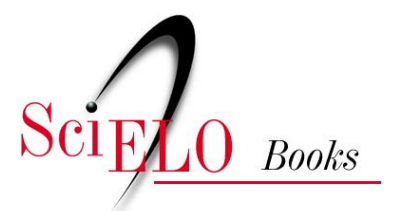

\title{
Franceses e espanhóis
}

\author{
Capistrano de Abreu
}

ABREU, C. Franceses e espanhóis. In: Capitulos da história colonial [online]. Rio de Janeiro: Centro Edelstein de Pesquisa Social, 2009. pp. 49-65. ISBN: 978-85-7982-071-7.

https://doi.org/10.7476/9788579820717.0007.

\section{() pobuntiv}

This work is free of known copyright restrictions. http://creativecommons.org/publicdomain/mark/1.0/

Este trabalho está livre de restrições de direito de autor e/ou de direitos conexos conhecidas.

http://creativecommons.org/publicdomain/mark/1.0/

Esta obra está libre de restricciones conocidas de derechos autorales. http://creativecommons.org/publicdomain/mark/1.0/ 


\section{FRANCESES E ESPANHÓIS}

Em 1580 extinguiu-se a dinastia de Avis. Filipe II da Espanha, neto de d. Manuel, apoiando suas pretensões pelas armas, sucedeu a d. Henrique, e incorporou à casa de Habsburgo o trono português. Com Portugal cairam todas suas possessões sob o domínio espanhol. Para o Brasil as primeiras consequências deste estado de cousas foram favoráveis. Os limites naturais da colônia indicaram-nos o Amazonas e o Prata. De ambos separavam o povoado distâncias sempre enormes. Agora, se as distâncias persistiam as mesmas, podia-se em compensação concentrar os esforços num só sentido, em vez de dissipá-los por ambos. Esperaria o Prata, já ocupado em parte; urgia senhorear o Amazonas, ainda não investido, mas já cobiçado por diversas nações. Assim, caminho do Prata o trabalho reduziu-se a mera consolidação, ao estreitamento de malhas; para o Amazonas a expansão colonizadora moveu-se acelerada. Por isso, preferindo a ordem cronológica para a expansão amazônica, seguiremos a ordem geográfica no outro extrerno.

Vindo do sul, encontrava-se a Cananeia habitada por gente ida da capitania de São Vicente, que também procurava recôncavo de Angra dos Reis, e já se comunicava com a cidade de São Sebastião, pela baixada de Santa Cruz, onde os jesuítas começavam uma fazenda famosa. Nas terras do Cabo Frio os franceses continuavam a frequentar, naturalmente menos a miúdo e com menor proveito.

Por fim, Constantino Menelau, depois de vencê-los, obstruiu o porto, e Estevão Gomes estabeleceu uma pequena fortaleza. Flagelados pelas bexigas, os Guaitacás aproximaram-se dos brancos que os poderiam socorrer. Para a conciliação muito contribuiu o jesuíta Domingos Rodrigues.

Este mesmo Domingos Rodrigues, mais tarde egresso da Companhia de Jesus, em Ilheus, Álvaro Rodrigues Adôrno, na Cachoeira, levaram a bom termo a pacificação dos Aimorés. Por este modo desde o Rio até a cidade do Salvador cessaram temporariamente suas devastações os tão temidos Tapuias do litoral, que só reaparecem pelos meados do século.

Ao Norte da Bahia apresenta-se como mais notável o fato da conquista de Sergipe. Desde os últimos tempos de Mem de Sá a empresa 
afigurara-se fácil, pois não cessavam mensagens pedindo aos padres da Companhia que fossem até lá levar a boa nova. Com os dois jesuítas mandados a este fim partiram os soldados e mamalucos, ávidos de escravos, que plantaram a sizania entre os Tupinambás, e alienaram sua confiança. Todas as desconfianças confirmou o governador Luís de Brito de Almeida no ano de 1574, fazendo guerra implacável aos índios, aprisionando uns, afugentando outros, devastando aquelas comarcas, por simples desfastio destruidor, poderia crer-se; pois durante cerca de dois decênios quedou estacionária a obra colonizadora.

Em fins de 1589, Cristóvão de Barros, governador interino por morte de Manuel Teles Barreto, repetiu de novo a tentativa, com melhor êxito. Parte da força seguiu por mar, parte por terra, e reunidos deram em várias cercas dos naturais, que foram derrotados.

Acossando estes, penetraram alguns aventureiros até o rio $\mathrm{S}$. Francisco. No território devoluto Cristóvão de Barros separou uma enorme sesmaria para o filho; esta serviu de craveira para outras, e dentro em pouco não havia mais o que distribuir. Com esta campanha os franceses perderam as antigas ligações no rio Real.

Na capitania de Duarte Coelho continuou o movimento para o rio S. Francisco. Fazendas de gado ou canaviais avançaram pelo território das Alagoas. Entre os povoadores desta região avulta o alemão Lins, que deixou larga descendência, e João Pais, de quem já se falou. Também daqui os franceses tiveram de retirar-se.

Nos primeiros anos do século 17, podia-se viajar e viajava-se efetivamente por terra da Bahia até Pernambuco sem encontrar resistência séria por parte dos naturais, vencidos ou afugentados da marinha. $\mathrm{O}$ único obstáculo ao livre trânsito apresentava a passagem dos rios maiores, direito real, como já vimos. Os rios menores eram passados nos vaus, e assim continuaram nos séculos seguintes; pelos vaus pode-se traçar a borda da primitiva ocupação litorânea.

Vejamos agora a marcha para o Amazonas.

Longo tempo estacionara o povoamento na ilha de Itamaracá e no continente fronteiro. Os Petiguares da serra entretinham boas relações com os colonos, que visitavam pacificamente as aldeias; os da praia, sempre amigos dos franceses, faziam com estes bons negócios na Paraíba, onde não os perturbavam os portugueses, contentes com breves excursões à procura de âmbar, abundante por aquelas plagas até o Ceará, e com o pau-brasil trazido do interior pelos próprios índios.

Em 1574, por causa de uma cunhã do sertão, desaveio-se a gente deste com a da Goiana, e começam as hostilidades. Foram assaltados e queimados dois engenhos, e com esta fácil vitória mais se assanharam as paixões dos assaltantes. A guerra levianamente provocada havia de durar vinte e cinco anos. A mandado de Luís de Brito, o ouvidor-geral, Fernão da Silva, partiu para a Paraíba, afugentou a indiana com simples presença, lavrou autos que fícaram só no papel. Frutuoso Barbosa, homem de fortunas, ofereceu-se à metrópole para ultimar a conquista se lhe concedessem certas mercês. Com elas chegou em 1580 a Pernambuco, mas nada logrou fazer, porque um temporal atirou-o para as Antilhas e de lá à Europa. Da segunda vez não se animou a tentar estabelecimento algum; limitou-se a queimar navios franceses.

Em 1583 aportou à Bahia Diogo Flores Valdez, vindo de uma viagem malograda ao estreito de Magalhães. Ao governador insinuou-se como capaz desta conquista, e na monção seguinte partiu com uma armada espanhola e algumas embarcações portuguesas para Pernambuco. Organizou-se ao Recife uma expedição marítima e outra terrestre. Por mar, Diogo Flores chegou sem embaraço a seu destino, queimou alguns navios franceses carregados de pau-brasil, fundou um forte, nele deixou uma guarnição de compatriotas seus; a gente ida por terra saiu vitoriosa de vários reencontros e fundou um povoado, a cidade Filipeia, como a chamou Frutuoso Barbosa, em honra do dinasta reinante. O castelhano Castejón ficou por alcaide do forte, e Frutuoso Barbosa tomou conta da cidade.

Amassaram-se mal o chefe civil e o chefe militar; a discórdia lavrou entre castelhanos e portugueses. Os Petiguares, aterrados pelos primeiros embates, voltaram logo em chusmas densas e mais arrogantes. Guiavamnos franceses dos diversos navios queimados, sedentos de vingança, cônscios da importância capital desta partida, em que se disputavam terrenos de seu domínio exclusivo durante tantos anos. Castejón portou-se com bravura; socorros de Pernambuco expedidos por Martim Leitão, ouvidor-geral, nunca lhe faltaram. O próprio ouvidor-geral lá foi, em março de 1586, com quinhentos homens brancos e muitos índios em sua companhia. Mas os índios e os franceses continuavam cada vez mais afoitos 
e mais ardentes. Desanimado, Frutuoso Barbosa desistiu de seus direitos e retirou-se para Olinda. Castejón resistiu até junho; ao retirar-se tocou fogo no forte, quebrou o sino, meteu a pique um navio, lançou a artilharia ao mar. Ficava aniquilado todo o trabalho.

Anos antes, aventureiros pernambucanos, guerreando no rio $\mathrm{S}$ Francisco, houveram-se tão aleivosamente com os Tabajaras, os antigos e fiéis aliados desde o tempo de Duarte Coelho, que estes o mataram a todos, fugiram dos lugares nefastos, e por uma das gargantas da Borborema procuraram a terra da Paraíba para combater os brancos, aliando-se embora aos Petiguares, seus inimigos hereditários e irreconciliáveis da língua geral. Martim Leitão, quando saiu de Olinda em auxílio de Castejón, reconheceuos e entabulou negociações, esperando trazê-los à antiga amizade. Os Tabajaras não se deixaram requestar e prepararam-se para o combate: traiuos a sorte, apesar da valentia de Braço de Peixe e Assento de Pássaro, os dois chefes tupiniquins.

Esta derrota despertou o ódio avito dos Tupinambás que se tornaram contra os novos aliados, malsinando-os de covardes, tratando-os de traidores, obrigando-os a tornarem às terras donde vieram. Soube-o Martim Leitão, e mandou emissários a Piragibá, prometeu o esquecimento das injúrias recentes, anunciou auxílios prontos, instou por sua permanência, renovando as antigas pazes. Cedeu o Braço de Peixe; com a intervenção de João Tavares, escrivão de órfãos de Olinda, passaram os Tabajaras a combater ao lado dos portugueses.

Em agosto 5, dia de Nossa Senhora das Neves, João Tavares recomeçou a obra aniquilada pela defecção de Castejón, auxiliada agora pela gente de Braço de Peixe e Assento de Pássaro, mas perturbada sempre pelos Petiguares e pelos franceses. Mais duas vezes tornou Martim Leitão à Paraíba. Sua ação sempre fecunda e prestigiosa pode resumir-se em poucas palavras: queimou navios, queimou pau-brasil já cortado, queimou aldeias, arrancou plantações, inutilizou mantimentos na baía da Traição, na serra de Copaoba, no Tijucopapo.

Em maio de 1587, Martim Leitão considerou terminada sua missão, e voltou para Pernambuco, depois de lançar os alicerces para um engenho real. Enganava-se, porém; prosseguiram constantes as guerras durante mais de dez anos, no sertão, no litoral com as naus francesas, que chegaram a cercar a fortaleza do Cabedelo, com os Petiguares, a quem a presença dos franceses, privados de ir para sua terra pela queima das naus que os deviam conduzir, comunicaram uma audácia e uma persistência bem alheias à índole indígena. Destes incidentes ignoramos a história; a crônica apenas guarda os nomes de Pero Lopes, Feliciano Coelho, Pero Coelho, talvez Ambrósio Fernandes Brandão, o autor possível dos Diálogos das Grandezas do Brasil. Do lado dos franceses a tradição lembra Rifault, cujos feitos não podem aliás ser precisados á falta de documentos. Tantos anos agitados e tão desesperada resistência patentearam a urgência de ocupar o rio Grande onde os inimigos perenemente se refaziam. De lá sairam uma vez treze navios para tomar Cabedelo e o combate durara de uma sexta a uma segunda-feira. Em suas águas chegaram a se reunir vinte navios procedentes de França. Muitos franceses mestiçaram com as mulheres indígenas, muitos filhos de cunhãs se encontravam já de cabelo louro: ainda hoje resta um vestígio da ascendência e da persistência dos antigos rivais dos portugueses na cabeleira de gente encontrada naquela e nos vizinhos sertões de Paraíba e Ceará.

A expedição ao rio Grande, concebida no governo de d. Francisco de Sousa, aparelhada de recursos abundantes, dirigida desde Pernambuco por Manuel de Mascaranhas Homem, lugar-tenente do donatário, e Alexandre de Moura, que devia suceder no mando, repartiu-se por terra e por mar. A divisão marítima, comandada por Manuel de Mascaranhas, a quem se agregou Jerônimo de Albuquerque, chegou felizmente a seu destino em janeiro de 1598. Parte da divisão terrestre, encabeçada por Feliciano Coelho, capitão-mor da Paraíba, venceu a resistência dos inimigos, mas dissolveu-se ante uma epidemia de bexigas. A praga passou também ao inimigo, e serviu para dar folgas a Manuel de Mascaranhas, aliás acometido mais de uma vez no forte que começara.

Em março, Feliciano Coelho outra vez marchou para o rio Grande, depois de reunir as suas forças, reduzidas agora à metade pela doença e pela retirada do contigente de Pernambuco. Com este reforço, Manuel de Mascaranhas concluiu o forte dos Reis Magos, e entregou-o a Jerônimo de Albuquerque, nomeado para comandá-lo. À sua sombra medrou o que é hoje a cidade de Natal. Na volta, Mascaranhas e Coelho afastaram-se da costa e fizeram novas devastações entre a indiada do sertão.

Nas veias de Jerônimo de Albuquerque circulava sangue petiguar de sua mãe, Maria do Arco-Verde, e disto não se envergonhava, antes o vemos 
em mais de uma conjuntura proclamando a sua extração. Assim devia sorrir-lhe a ideia de conciliar os parentes, reduzidos aos últimos apuros por tantos trabalhos e tão continuada perseguição, e agora forçosamente abandonados pelos franceses. A um índio aprisionado, principal e feiticeiro, incumbiu esta missão, depois de bem instruí-lo no que devia dizer. O pensamento humanitário foi coroado do melhor êxito, graças sobretudo às mulheres que, informa um contemporâneo, enfadadas de andarem com o fato continuamente às costas, fugindo pelos matos sem poder gozar de suas casas, nem dos legumes que plantavam, traziam os maridos ameaçados que se haviam de ir para os brancos, porque antes queriam ser suas cativas que viver em tantos receios de contínuas guerras e rebates. Por ordem de d. Francisco de Sousa as pazes foram juradas solenemente na Paraíba, a 15 de junho de 1599. Serviu de intérprete frei Bernardino das Neves, filho de João Tavares, escrivão de órfãos de Olinda, já nosso conhecido. Deste ato resultou nascer e criar-se na amizade dos portugueses, Antônio Camarão, um dos heróis da luta contra Holanda.

A conquista do rio Grande tinha logrado afastar os franceses e desenganar os índios numa grande extensão de terreno; mas significava, mais que isto, o encurtamento da distância ao Maranhão e Amazonas. Desde os primeiros tempos do governador Diogo Botelho surge com força a ideia de consumar a obra, e trata-se de chegar às regiões onde a mão da natureza assentara os limites do país.

Obrigou-se a incorporar o Maranhão Pedro Coelho de Sousa, cunhado de Frutuoso Barbosa, que com séquito numeroso partiu da Paraíba e chegou ao Jaguaribe em 1603. Os índios daquela ribeira, a princípio esquivos, deixaram-se enlear pelas promessas dos intérpretes e todo o sáfio litoral cearense foi percorrido em paz. Só na serra de Ibiapaba, aliás seminário dos amigos Tabajaras, apareceu resistência, promovida por franceses. Venceu-a Pedro Coelho e desceu a serra em busca do rio Punará, ou Parnaíba, como é chamado hoje. Como sua gente não quisesse ir mais adiante teve que retroceder.

Tudo correra bem até aí, tudo começou logo a se danar. Pedro Coelho, na volta para o povoado, capturou os índios que pode, indiferentemente, Tabajaras, velhos amigos, e Petiguares, aliados recentes. Quando, depois de os ter distribuído pela Paraíba e Pernambuco, novamente tornou ao Ceará, achou a situação insustentável e foi obrigado a retirar-se.
Sua retirada lastimável balizaram cadáveres, vítimas dos areais candentes, da fome e da sede.

No provincialado de Fernão Cardim, governando d. Diogo de Menezes, dois jesuítas, Francisco Pinto e Luís Figueira, foram incumbidos de chegar ao Maranhão. Levaram em sua companhia para restituí-los à liberdade alguns dos índios capturados por Pedro Coelho e sua gente; com algum esforço venceram as desconfianças do gentio, atravessaram a serra do Uruburetama, e chegaram a Ibiapaba, bem acolhidos, apesar de tudo. Preparavam-se para prosseguir, quando uns Tapuaias assaltaram a aldeia em que assistiam, e mataram Francisco Pinto. Luís Figueira escapou e tornou para Pernambuco, onde anos mais tarde escreveu esta trágica odisseia em carta felizmente hoje salva da voragem do tempo.

Nem a expedição numerosa, aparelhada para a guerra, de Pedro Coelho, nem a missão pacífica dos jesuítas adiantara um passo à questão de avanço para a costa Leste-Oeste, destinada talvez a adiamento indefinido, se não interviesse Martim Soares Moreno. Chegara de Portugal em 1602, e Diogo de Campos, seu tio, sargento-mor de estado, o incorporou à primeira expedição de Pedro Coelho, para aprender a língua da terra e familiarizar-se com os costumes. Contava apenas dezoito anos. Realizou os desejos do tio de modo superior, e tão bem se houve entre os indígenas que Jacaúna, chefe petiguar, distinguiu-o da turba malfeitora e votou-lhe amor de pai. Nomeado tenente da fortaleza dos Reis-Magos, cultivou estas relações, mais de uma vez visitou o fiel amigo, sempre esperançado de dissipar as prevenções e rancores. Afinal o índio permitiu-lhe levar um filho à Bahia, apresentá-lo ao governador, d. Diogo de Meneses, e consentiu-lhe viesse estabelecer-se com dois soldados. Pode assim lançar, junto ao minúsculo rio Ceará, os fundamentos de um forte, onde resistiu aos ataques da gente não sujeita a Jacaúna; com o auxílio deste tomou duas naus estrangeiras, nu e pintado de genipapo, à maneira de seus auxiliares. Aquele ponto, até ali conhecido como excelente aguada dos franceses, passou desde então a ser evitado.

No governo de Gaspar de Sousa projetou-se avançar mais para o Norte. Por sua ordem Jerônimo de Albuquerque partiu de Pernambuco com quatro barcos, em meados de 1613, nomeado capitão-mor da conquista do Maranhão, comandando cem homens brancos e muitos índios. Na passagem pelo Ceará levou consigo Martim Soares Moreno, como lhe fora permitido, 
e navegou até o Camocim, onde pretendeu fundar um forte. Por parecer pouco próprio este lugar, preferiu a enseada das Tartarugas, em Jererecuacara, onde deixou quarenta soldados num presídio; com o restante voltou por terra; os barcos mandou que costeassem como melhor pudessem e tornassem a Pernambuco.

Do Camocim expediu Martim Soares com vinte soldados ao Maranhão, a colher notícias que pudessem guiar no prosseguimento da conquista. Graças ao pequeno calado da lancha, Martim navegou muito pegado à terra, pode entrar pela boca do Preá, e alcançou por águas interiores a baía hoje chamada de S. José.

O nome e a amizade de Jacaúna serviram-lhe neste lance arriscado. Os Tupinambás receberam-no com aparente afabilidade, mas preparavamse para traí-lo, quando um deles descobriu-lhe a verdadeira situação. Havia um ano estavam aí franceses, com uma fortaleza artilhada de vinte peças, soldados, gente trazida em embarcações, sob o comando de Daniel de Latouche, senhor de la Ravardière. Ao mesmo tempo eram os franceses informados da presença do explorador português, e começavam a dar-lhe caça. Martim Soares escapou incólume com os seus e o índio amigo; o tempo, menos propício, atirou-o às costas da Venezuela, donde, por São Domingos, chegou a Sevilha em abril do ano seguinte, e tratou logo de mandar notícias para Pernambuco. Na mesma ocasião enviou com igual destino o piloto Sebastião Martins, mestre da lancha, que o acompanhara na peregrinação. Chegou no momento oportuno; Gaspar de Sousa tratava justamente de segunda e mais poderosa expedição para a nova conquista, e suas informações puderam ainda ser aproveitadas. Ainda esta vez Jerônimo de Albuquerque serviu de capitão-mor. Diogo de Campos, sargento-mor, ia por colateral. Recomendou-lhes o governador as maiores cautelas, lembrava a fortificação de algum ponto além do fortim deixado no ano anterior, a plantação de legumes de rápido crescimento, e indicou a conveniência de, desde Tutoia, ir parte da força por terra, parte por mar.

Depois de receber alguns reforços na fortaleza do Ceará, os expedicionários prosseguiram viagem a 29 de setembro de 1614, para o forte do Rosário, que meses antes provara forças com a gente de uma nau francesa destinada ao Maranhão. Feito o alarde da gente, apuraram-se 220 soldados portugueses, 60 marítimos e 300 índios frecheiros. Deviam acampar em Tutoia? Confessaram-se os pilotos ignorantes daquele trecho da costa: Bastião Martins só conhecia a barra do Preá; para lá se encaminharam a 12 de outubro, e na noite de 1613 se abalançaram por ela na maior confusão: "houve navios que iam tocando e dando grandes pancadas nos bancos ao entrar da barra, e, por não atemorizarem os que vinham de trás, calavam e paravam sem se ouvir uma palavra de rumor".

Iam a bordo moços impacientes e pouco disciplinados, ansiosos de medir-se com os franceses. Conseguiram do capitão-mor se prosseguisse levianamente pelo Preá a dentro, até avistar o inimigo. Era o melhor plano a executar, provou-o o resultado. Antes da viagem de Martim Soares Moreno, aquela entrada era desconhecida dos franceses; depois dela assentaram um forte ligeiro em Itapari; todo o esforço de Ravardière aplicara-se, porém, à defesa da baía de S. Marcos; nas suas fortificações depositavam-se a maior confiança. Claude 'Abbeville, missionário capuchinho, escrevia orgulhosamente: 'C' est donc niaizerie de penser que l'on puisse desloger les François de ce lieu, lors qu'ils y seront bien establis: \& le vouloir faire croire, outre que c'est trop raualler leur courage $\&$ faire trop peu d'estime de leur valeur \& generosité, Si ce n'est une pure malice n'est-ce pas temerité? \& que l'on en parle comme les aueugles des couleurs? Ceux qui ont veu la situation de cette Isle \& qui connoissent par experience les difficultez de ses advenuës, n'aduoueront iamais telle proposition qui ne procede que d'vn esprit timide". O ataque pela baía de S. José, devido mais à casual fraqueza da lancha de Martim Soares, deitava por terra todos estes arreganhos.

A 26 de outubro chegaram os expedicionários ao porto, depois chamado de Guaxenduba; a 28, começaram no continente o forte de Santa Maria. Na ilha fronteira, logo muitos fogos pareceram indicar a transmissão de notícias. Vieram à fala alguns índios, esquivos apesar de todas atenções e carinhos de Jerônimo de Albuquerque; negavam em geral a assistência dos franceses; um, porém, natural de Pernambuco, denunciou ataque próximo. De fato, a 12 de novembro, no quarto da lua, deu o inimigo nas embarcações e tomou três. A este seguiu-se outro de maior monta a 19. Os franceses desembarcaram duzentos infantes, mais de dois mil índios; como reserva ficou La Ravardière a bordo, acompanhado de cem soldados. Transportaram esta força cinquenta e sete embarcações, das quais as três tomadas alguns dias antes, e cinquenta canoas. Trataram de se entrincheirar e, para ganhar tempo, La Ravardière dirigiu uma carta ameaçadora a Jerônimo de Albuquerque. Sem dar-lhe resposta começaram os portugueses 
uma ofensiva desesperada, indo pela praia Diogo de Campos, Antônio e Albuquerque, filho do capitão-mor, e Jerônimo Fragoso; pelo monte Jerônimo de Albuquerque, Francisco de Frias e Manuel de Sousa de Sá.

Dos franceses, escreve este, morreram a espada e a arcabuzaços noventa e tantos, que logo ali ficaram, além dos que se afogaram fugindo para as embarcações, ao todo cento e sessenta; foram capturados nove; queimaram-se-lhes quarenta e seis canoas; tomaram-se ao todo duzentas armas de fogo, mosquetes e arcabuzes; dos selvagens averiguou-se depois que faltavam quatrocentos, a maior parte mortos afogados. De parte dos portugueses as perdas foram insignificantes.

A derrota quebrantou o ânimo de La Ravardière. Em vez de procurar desforrar-se logo, entabulou a 21 uma correspondência com Jerônimo de Albuquerque, concebida em termos duros, que foi abrandando gradualmente. Os portugueses achavam-se em situação difícil: o inimigo dominava as entradas com sua frota; socorros só poderiam vir pelo Preá, e o Preá só admitia vasos de pequeno calado. Apesar de tudo sua confiança mantinha-se inalterável: "somos homens que um punhado de farinha e um pedaço de cobra quando o há nos sustenta”, escrevia Jerônimo de Albuquerque; "somos gente que não podemos nadar tanto mar quanto há daqui à Espanha; pelo que ainda que hoje tendes a barra, nós temos a terra que pisamos, a qual sempre será de nossos corpos até que Sua Majestade d'el-rei da Espanha, nosso senhor, cujo tudo é, outra coisa ordene", segundava mais difuso Diogo de Campos.

Da correspondência e das práticas nasceu a ideia de tréguas. As duas metrópoles estavam amigas e aliadas no velho mundo, por que se degladiariam neste? A 27, convencionou-se a suspensão das hostilidades até fim de dezembro de 1615; nem os franceses iriam ao continente, nem os portugueses à ilha, e evitariam ambos entrar em contacto com os índios de uma e outra jurisdição; seriam permutados sem resgate os prisioneiros; ficaria o mar franco aos portugueses; socorro de gente de guerra não suspenderia o armistício; a nação obrigada a retirar-se teria três meses para os aprestos; dois representantes de cada beligerante iriam à corte de Madrid e à de Paris, saber de Suas Majestades Católica e Cristianíssima suas vontades sobre quem deveria ficar no Maranhão.

Depois disso o capitão-mor da conquista mandou Manuel de Sousa de Sá, num caravelão, a Pernambuco levar a notícia do sucedido ao governador geral. A nau Regente, que já se batera com a guarnição do Rosário, em Jererecuacara, partiu a 16 de dezembro, levando os emissário Du Prat e Gregório Fragoso para França. A 4 de janeiro de 1615 saiu para Portugal Diogo de Campos com Mathieu Maillart, numa caravela comprada a este por 500 cruzados; a 3 de março apresentava-se ao vice-rei d. Aleixo de Menezes. O sargento-mor aproveitou a travessia para escrever a Jornada de Maranhão.

Na corte foi acolhido com frieza o resultado da expedição, e a má vontade aumentou quando inesperadamente chegou Manuel de Sousa de Sá, enviado a Pernambuco mas levado pelos ventos e correntes às Indias ocidentais, donde lhe deram condução para a Europa. Conhecida a versão de Manuel de Sousa, diferente em pontos essenciais da de Diogo de Campos, aprestou-se para o Maranhão um patacho com munições, pólvoras e mais coisas necessárias, que em começos de junho passou pelo Ceará. Nele parece ter voltado Martim Soares, com o posto de sargento-mor, na ausência do tio. Falou-se em castigar este, mas prevaleceu o alvitre de mandá-lo com Sousa de Sá a Gaspar de Sousa, a quem com maior empenho se ordenou a ultimação da empresa.

Não se descuidara o governador. Em junho mandara Francisco Caldeira de Castelo Branco, antigo capitão-mor do Rio Grande, comandando uma armada composta de um patacho, duas caravelas e um caravelão grande, que chegou a Santa Maria de Guaxenduba em 1 de julho, fazendo a viagem por fora do Preá. La Ravardière foi, apesar da trégua, intimado a abandonar a terra, e, depois de relutar, cedeu em promessa; mas, porque rebentassem discórdias entre os dois chefes portugueses, foi-se deixando ficar, Jerônimo de Albuquerque transferiu-se para a ilha, onde fundou uma cerca e um forte, chamado de S. José. Provavelmente vem daí o nome atual desta baía.

Manuel de Sousa encontrou o governador geral em Pernambuco, e deu-lhe cartas e ordens. Sem demora Gaspar de Sousa aprestou nove navios, cinco dos quais grandes, com mais de novecentos homens, muito armamento e dinheiro, plantas e gado para povoarem a terra. Conferiu o comando a Alexandre de Moura que, partindo a 5 de outubro do Recife, a 17 chegava ao Preá, onde breve se convenceu de não serem para aquele canal as suas embarcações. Cumpria navegar por fora, fazer sondagens, arrostar a baía de S. Marcos, as terríveis fortificações, 
inexpugnáveis no sentir de Abbeville. E não havia tempo a perder, pois a fortaleza de S. José se incendiara, e Jerônimo de Albuquerque, capitão-mor antes de nome que de fato, porque os portugueses achavam-se divididos em dois partidos dominados por ódios violentos, estava reduzido a pouca pólvora e às armas salvas do incêndio.

A 1 de novembro decidiu-se a investir a entrada de São Marcos; um patacho menor foi adiante, mostrando o caminho, e a armada surgiu fora do alcance da artilharia inimiga. Jerônimo de Albuquerque marchou por terra com forças; um posto foi guarnecido com oito peças de artilharia, cento e cinquenta soldados, duzentos frecheiros; cem homens com seis peças guardariam a entrada da barra. A 3 foi intimado La Ravardière a entregar a colônia e a fortaleza, com toda a artilharia e munições existentes dentro e fora dela, com todos os navios grandes e pequenos, sem por tudo receber indenização alguma. Obrigava-se Alexandre de Moura a dar condução para a França; os franceses se obrigariam a partir apenas recebessem os navios e deixassem reféns. E este favor se lhe faz, concluía, pelas alianças que hoje há entre os senhores reis Católico e Cristianíssimo.

A fortaleza foi entregue; em duas naus sem artilharia, mandadas separadamente, partiram os franceses para a pátria; La Ravardière teve de acompanhar o vencedor a Pernambuco. Anos mais tarde andava em Lisboa, requerendo mercês e alegando serviços, por haver largado o Maranhão com a sua fortaleza e artilharia. Assim, o mesmo ano de 1615 assistiu à derrocada final dos franceses depois de quase um século de resistência: em Cabo Frio, por mão de Constantino Menelau, no Maranhão pelo antigo capitão-mor de Pernambuco.

Trazia Alexandre de Moura instruções para expulsar os franceses do Pará e ir até o Amazonas. Como no Pará não existisse estabelecimento francês e o Amazonas estivesse desocupado, mandou em seu lugar Francisco Caldeira de Castelo Branco com cento e cinquenta homens, dez peças de artilharia e três embarcações. Além de colher outras vantagens, afastava do Maranhão um elemento perturbador. Em companhia de Castelo Branco seguiu um piloto francês, e o famoso Charles Desvaux "de quem ele, dito capitão-mor, deve fazer uma conta, com a cautela devida". Antônio Vicente Cochado foi como piloto.

Partiram no dia de Natal, correndo a costa, fazendo sondagens, dando fundo todas as noites, tomando as conhecenças da terra, numa extensão de cento e cinquenta léguas. Entraram na barra pela ponta de Saparará, e seguiram por entre ilhas, bem acolhidos pelo gentio disposto em seu favor, graças à derrota dos franceses; muitos dos naturais usavam cabelo comprido e de longe pareciam mulheres; encontraram notícias imprecisas de flamengos e ingleses que frequentavam aquelas regiões.

A 35 léguas do mar, na margem direita do Pará, Francisco Caldeira de Castelo Branco fundou a fortaleza, e chamou-a Presepe. Estava dado o primeiro passo para a ocupação do Amazonas.

Agora um rápido lancear do país, aí pelos anos de 1618, quando escrevia autor do Diálogo das Grandezas do Brasil, e Fr. Vicente do Salvador preparava-se para redigir sua história.

Os estabelecimentos fundados por portugueses começavam no Pará quase sob o Equador e terminavam em Cananeia além do trópico. Entre uma e outra capitania havia longos espaços desertos, de dezenas de léguas de extensão. A população de língua europeia cabia folgadamente em cinco algarismos.

A camada ínfima da população era formada por escravos, filhos da terra, africanos ou seus descendentes. Aqueles aparecem menos numerosos pela pouca densidade originária da população indígena, pelos grandes êxodos que os afastaram da costa, pelas constantes epidemias que os dizimaram, pelos embaraços, nem sempre inúteis, opostas ao seu escravizamento.

Acima deste rebanho sem terra e sem liberdade, seguiram-se os portugueses de nascimento ou de origem, sem terra, porém livres: feitores, mestres de açúcar, oficiais mecânicos, vivendo do seus salários ou do feitio de obras encomendadas; em geral o mecânico sabia vários ofícios, pois um só não garantia a subsistência, e ia trabalhar pelas fazendas quando a simplicidade das ferramentas o permitia ou os proprietários possuiam a ferramenta em casa.

Entre os proprietários rurais ocupavam lugar modesto os lavradores de mantimento e os criadores de gado: a criação avultava somente a uma e outra margem do baixo São Francisco: seu grande desenvolvimento se operou mais tarde, quando se separou da lavoura e invadiu os campos e as catingas do interior. 
Coroava esta hierarquia o senhor de engenho. Havia engenhos movidos por água e por bois; servidos por carros ou por barcos; situados à beira-mar ou mais apartados, não muito, porque as dificuldades de comunicações apenas permitiam arcos de limitados raios. $\mathrm{O}$ engenho real devia possuir grandes canaviais, lenha abundante, boiada capaz ou barcos e barqueiros suficientes, escravatura, aparelhos diversos, moendas, cobres, fôrmas, casas de purgar, pessoal adestrado para o preparo do açúcar, pois a matéria prima passava por diversos processos antes de ser entregue ao consumo: alguns possuiam igreja, capelão melhor remunerado que os vigários, e às vezes incumbido de ensinar rudimentos de leitura à meninada. $\mathrm{O}$ senhor de engenho opulento remetia a safra diretamente para o Reino, e recebia o pagamento do além-mar em fazendas finas, vinhos, farinha de trigo, em suma, coisas de gozo ou de luxo.

A casa da gente rica representava uma economia autônoma: o nec est quod putes illum quidquam emere, omnia domi nascuntur, de Petrônio, não podia ser praticado ao pé da letra, mas correspondia até certo ponto à realidade. Para os escravos fiava-se e tecia-se a roupa; a roupa da família era feita no meio dela; da alimentação, fornecida por peixe de água doce ou salgada, mariscos apanhados nos mangues ou caça, estavam encarregados os escravos; a criação miúda de voláteis, ovelhas, cabritos e porcos evitava as surpresas de hóspedes da última hora: não havia açougues ou mercados:

as casas dos ricos (ainda que seja á custa alheia, pois muitos devem o que têm) andam providas de todo o necessário, pois têm escravos pescadores e caçadores, que lhes trazem a carne e o peixe, pipas de vinho e azeite que compram por junto, nas vilas muitas vezes se não acha isto de venda.

A mercatura representava-se por embarcadiços vindos do Reino com carregamentos que tratavam de liquidar, de modo a voltar no mesmo navio, ou de mascates que iam pelos lugares mais afastados, a vender miudezas. Nas transações dominava a permuta ou empréstimos de gêneros; transações a dinheiro não se conheciam ou eram raríssimas, e como ninguém sabia aproximadamente de suas posses, o endividamento era geral.

$\mathrm{Na}$ economia naturista, já foi observado, por um economista recente, nunca se produzem demais os gêneros consumidos em casa; se há superabundância de algum, guarda-se, dá-se ou deixa-se estragar; daí, a hospitalidade, as festas pantagruélicas e também o jogo. Talvez nas paradas achasse seu melhor emprego o pouco dinheiro girante; o resto ia em festas eclesiásticas ou profanas.

A ausência de capitais restringia muito as satisfações da vida coletiva: não havia fontes, nem pontes, nem estradas; se por alguma circunstância favorável, construía-se alguma, à falta de conservação estragava-se ou ficava de todo arruinada. Como não havia dinheiro, os impostos eram levados à praça, e o contratador pagava-se em gêneros. Só as casas de misericórdia eram até certo ponto devidas à ação incorporada. As sedes das capitanias, mesmo as mais prósperas, reduziam-se a meros lugarejos; a gente abastada possuía prédios nas vilas, mas só os ocupava no tempo das festas; a população permanente constava de funcionários, mecânicos, regulares ou gente de vida pouco edificante.

Ajunte-se a isto a natural desafeição pela terra, fácil de compreender se nos transportamos às condições dos primeiros colonos, abafados pela mata virgem, picados por insetos, envenenados por ofídios, expostos às feras, ameaçados pelos índios, indefesos contra os piratas, que começaram a surgir apenas souberam de alguma coisa digna de roubar. Mesmo se sobejassem meios, não havia pendor a meter mãos a obras destinadas aos vindouros; tratava-se de ganhar fortuna o mais depressa possível para ir desfrutá-la no além mar. Informa-nos Gandavo que os velhos acostumados ao país não queriam sair mais. Seriam estes seus primeiros entusiastas.

Desafeição igual à sentida pela terra nutriam entre si os diversos componentes da população. Examinando superficialmente o povo, discriminaram-se logo três raças irredutíveis, oriunda cada qual de continente diverso, cuja aproximação nada favorecia. Tão pouco próprios a despertar simpatia e benevolência, antolhavam-se os mestiços, mesclados em proporção instável quanto à receita da pele e dosagem do sangue, medidas naqueles tempos, quando o fenômeno estranho e novo, em toda a energia do estado nascente, tendia a observação ao requinte e superexcitava os sentidos, medidas e pesadas com uma precisão de que não podemos mais formar ideia remota, nós afeitos ao fato consumado desde o berço, indiferentes às peles de qualquer aviação e às dinamizações do sangue em qualquer ordinal.

A desafeição entre as três raças e respectivos mestiços lavrava dentro de cada raça. O negro ladino e crioulo olhava com desprezo o parceiro boçal, alheio à língua dos senhores. $\mathrm{O}$ índio catequizado, reduzido e 
vestido, e o índio selvagem ainda livre e nu, mesmo quando pertencentes à mesma tribo, deviam sentir-se profundamente separados. O português vindo da terra, o reinol, julgava-se muito superior ao português nascido nestas paragens alongadas e bárbaras; o português nascido no Brasil, o mazombo, sentia e reconhecia sua inferioridade.

Em suma, dominavam forças dissolventes, centrífugas, no organismo social; apenas se percebiam as diferenças; não havia consciência de unidade, mas de multiplicidade. Só muito devagar foi cedendo esta dispersão geral, pelos meados do século XVII. Reinóis e mazombos, negros boçais e negros ladinos, mamalucos, mulatos, caboclos, caribocas, todas as denominações, enfim, sentiram-se mais próximos uns de outros, apesar de todas as diferenças flagrantes e irredutíveis, do que do invasor holandês: daí uma guerra começada em 1624, e levada ao fim, sem desfalecimentos, durante trinta anos. Em São Vicente, no Rio, na Bahia, e em outros lugares, por meios diferentes, chegou-se ao mesmo resultado.

Sobre o modo de administração de toda esta gente informa-nos a folha geral do estado, organizada em 1617. Subiam todas as despesas públicas a cinquenta e quatro contos, cento e trinta e oito mil, duzentos e noventa e oito réis, repartidos pelas quatro rubricas de igreja, justiça, milícia e fazenda.

Constituía todo o país uma só diocese; o Bispo assistia na Bahia com o Cabido; dois administradores, um para as capitanias do Norte e estabelecido na Paraíba, outra para as capitanias do Sul e residindo no Espírito Santo, seguiam-se em hierarquia; cada capitania formava uma freguesia, com seu vigário e coadjuntor, exceto a de S. Vicente, que contava as vigararias de Itanhaém, São Vicente, Santos e São Paulo; a de Espírito Santo, com as de Vitória e E. Santo; a da Bahia com as de Vila-Velha, Santo Amaro, S. Iago, Peruaçu, Paripe, Matoim, N. S. do Socorro, Sergipe do Conde, Taparica, Passé, Pirajá, Cotegipe, Tamari e Sergipe del Rei; a de Pernambuco com as de Olinda, São Pedro, Recife, S. Lourenço, Igaraçu, S. Antônio, Várzea, Moribeca, S. Amaro, Pojuca, Serinhaém e Porto Calvo; a de Itamaracá, com a da ilha e a da Goiana. A todo este pessoal o governo pagava ordenado e ordinária para a celebração do culto; para isso o rei arrecadava o dízimo, como grão-mestre da Ordem de Cristo.

Havia colégio de jesuítas, conventos Capuchos, Carmelitas ou Beneditinos na Bahia, Rio, Espírito Santo, Pernambuco, e todos recebiam auxílios sob diversas formas, em gêneros ou dinheiro. Quase todas as capitanias sustentavam casas de misericórdia, que o governo socorria.

À frente da justiça estava a Relação instalada na Bahia com um numeroso pessoal de desembargadores, ouvidor-geral, etc.; nas capitanias reais parece que a jurisdição de primeira instância cabia aos juízes ordinários, renovados anualmente; as dos donatários possuíam ouvidores que muitas vezes eram os próprios capitães-mores: pouco informa a este respeito a folha geral.

Encabeçava o corpo da fazenda o provedor-mor, estabelecido na capital, a quem estavam subordinados em cada capitania o provedor e escrivão da fazenda, o almoxarife e o porteiro das alfândegas.

Ao lado das capitanias de donatários, São Vicente, S. Amaro, Espírito Santo, Porto Seguro, Ilhéus, Pernambuco e Itamaracá, havia as capitanias reais do Rio, Bahia, Sergipe, Paraíba, Rio Grande, Ceará, Maranhão, Pará

Chefe da milícia e em geral da administração era o Governador Geral com assento na Bahia. A milícia era representada pela tropa paga, e pelas ordenanças, espécie de guarda nacional.

E agora vistas as vantagens do domínio espanhol na eliminação completa dos franceses e na rapidez da marcha para o Amazonas, vejamos o reverso da medalha, nas guerras flamengas dele originadas. 